\title{
Dating the Cart-Ruts of Terceira Island, Azores, Portugal
}

\author{
Félix Rodrigues ${ }^{1,2 *}$, João Madruga ${ }^{1,2}$, Nuno Martins ${ }^{3}$, Fábio Cardoso ${ }^{1}$ \\ ${ }^{1}$ Faculty of Agrarian and Environmental Sciences, University of the Azores, Angra do Heroísmo, Portugal \\ ${ }^{2}$ Institute of Investigation on Agronomic and Environmental Technologies of the Azores, Angra do Heroísmo, Portugal \\ ${ }^{3}$ Faculty of Economics and Management, Universidade Católica Portuguesa, Porto, Portugal \\ Email: ^antonio.ff.rodrigues@uac.pt
}

How to cite this paper: Rodrigues, F., Madruga, J., Martins, N., \& Cardoso, F. (2018). Dating the Cart-Ruts of Terceira Island, Azores, Portugal. Archaeological Discovery, 6, 279-299.

https://doi.org/10.4236/ad.2018.64014

Received: July 5, 2018

Accepted: August 6, 2018

Published: August 9, 2018

Copyright (C) 2018 by authors and Scientific Research Publishing Inc. This work is licensed under the Creative Commons Attribution International License (CC BY 4.0).

http://creativecommons.org/licenses/by/4.0/

(c) (i) Open Access

\begin{abstract}
Unlike other cart ruts found elsewhere in the world, the Azorean cart-ruts, engraved on volcanic stone, at the middle of the Atlantic, raise many questions: How old are they? Who created them? Were they made during a short or long time? These mysteriously enigmatic parallel grooves are noticed on the hard volcanic rock of the nine Azorean Islands in several locations. Recent scientific evidences have provided some support to the hypothesis of human presence in the Azores Islands before Portuguese settlement during the $15^{\text {th }}$ century. Are the Azorean cart-ruts pre-Portuguese? Here we try to establish a chronology for the cart-ruts of Terceira Island, Azores, Portugal, using a historical approach, a geological approach and also a ${ }^{14} \mathrm{C}$ dating approach, the last one obtained by dating a placic horizon found in the grooves of the cart-ruts named "Passage of the Beasts", which indicates the presence of human activity in the island at least during the $11^{\text {th }}$ century, or probably before. The date obtained is consistent with another date achieved through similar methods for a man-made basin in the same island and is also consistent with the historiographical records.
\end{abstract}

\section{Keywords}

Azores, Cart-Ruts, Ox-Carts, Pre-Portuguese, Volcanic Activity

\section{Introduction}

There are cart-ruts all around the world considered to be ancient. But are the Azorean cart-ruts ancient? Addressing this question can be confusing, because all cart-ruts in the Azores have been considered to be man-made within the context of the Portuguese economy of the islands from the $15^{\text {th }}$ to $17^{\text {th }}$ centuries. 
We need to look at the cart-ruts phenomenon more holistically, taking into account several features across time and places, and with multiple scientific perspectives (stemming from history, ethnography, physics, chemistry, geology, genetic, ecology, economy, culture, etc.), and if necessary, to change the existing paradigm. Indeed, recent scientific evidence suggests the human presence on the Azores Islands before the arrival of the Portuguese settlers in the $15^{\text {th }}$ century. These evidences include a genetic study on the Mus musculus (Gabriel, Matias, \& Searle, 2013), which connected the genetic attributes of the house mouse in some of the Azores islands with genetic characteristics of house mouse populations in Northern Europe, suggesting earlier navigational routes that predate the Portuguese arrival, as an explanation for this phenomenon. Another study links the genetic characteristics of the Azorean weasel (Mustela nivalis), usually introduced on the islands as a predator for the mouse, to the Mediterranean Region and not to the Iberian Peninsula, again suggesting earlier navigational routes than Portuguese settlement's (Rodrigues et al., 2017). However, despite their usefulness for tracing possible navigational routes, genetic studies provide no evidence as far as dating is concerned, and hence must be associated with other studies when making inferences on possible human presence in the islands, including scientific dating, historiographical elements, and archaeological context.

At the Portuguese Madeira Island, closer to Europe and Africa than the Azores, ancient bones of mice were obtained and dated (Rando, Pieper, \& Alcover, 2014). They date from $1033 \mathrm{BP} \pm 28 \mathrm{BP}$ and document the earliest evidence for the presence of mice on the island. The result suggests that those humans could have reached Madeira around four centuries before Portugal officially took possession of the island. A singular and unpublished result appeared in late 1999, during the process of installing a water catchment, at Porto Santo Island, Madeira Archipelago, where construction crews happened upon a $1300 \pm$ 100-year-old skeleton, dated by radiocarbon at the Royal Institute for Cultural Heritage on Brussels (Centro de Estudos de Arqueologia Moderna, 2017).

Recent scientific evidence on dating has arisen in a novel analysis of lake sediments in São Miguel Island (Rull et al., 2017), which led to the conclusion that there was human activity in the island at least in the $13^{\text {th }}$ century, well before Portuguese arrival at the Azores in the $15^{\text {th }}$ century. The evidence of such human activity includes deforestation, the cultivation of various cereals, animal husbandry and the use of fire, although human impact on the island was more limited before the Portuguese arrival than after. Analysis of a man-made bowl in Terceira Island, which inside sediments was dated through Accelerator Mass Spectrometry at Beta Analytic, Miami, is highly suggestive of human presence in the island at least during the $11^{\text {th }}$ century, if not before (Rodrigues et al., 2015).

The studies mentioned above were led by six entirely different groups of researchers, most of whom were not concerned with finding evidence of pre-Portuguese presence in the Azores Islands or Madeira Islands, and obtained such evidence as a by-product of the investigations they were conducting, be it genetic studies on rodents, the study of natural and anthropogenic dynamics in 
vegetation or dwelling activities. So it is quite natural that the studies above have not yet led to an integrated picture of human presence in the Azores Islands before Portuguese arrival. This is compounded by the fact that studies on this matter (Rodrigues, 2013; Pimenta et al., 2013; Rodrigues, 2015; Rodrigues et al., 2015; Ribeiro et al., 2017) are still in their infancy, so there is no clear archaeological context that enables solid inferences as to which specific human culture may have existed in the Azores Islands before Portuguese arrival.

Within the Azorean historiography, the topic is addressed by Francisco Ferreira Drummond (1859), who produced the most complete and authoritative history of Terceira Island, and argues that several cart-ruts in the island cannot be explained as a result of Portuguese activity.

Through an analysis of official documents of the Praia da Vitória city hall (which by then was called "Vila da Praia") from the $16^{\text {th }}$ century, analysis of the economic activity in Terceira Island in the $17^{\text {th }}$ and $18^{\text {th }}$ century and on the interviews he did to the elders on the island who told him that their parents had already told them about these ruts, Drummond (1859) concludes that the cart-ruts found in Terceira Island were not made after the Portuguese arrival, and must have been produced by some other human population that lived on the island before the Portuguese. These cart-ruts also puzzled Charles Darwin when he arrived at Terceira Island in his return journey from his voyage in the Beagle, given their similarity with those existing at Pompeii-see Martins (2015) for a discussion of Darwin's remarks, as well as for a contextualization of Drummond's contribution within the Azorean historiography.

While Drummond's inference is indeed the most authoritative writing within Azorean historiography on this matter, which is certainly reinforced by Darwin's remarks (Martins, 2015), no scientific evidence has been produced so far regarding the cart-ruts builders or activities that produce them on Terceira Island. The present work attempts to address this gap in the emerging literature on this subject, by presenting the first scientific dating of the cart-ruts on the Azores.

\section{Existing Explanations of the Cart-Ruts on Terceira Island}

Cart-ruts around the world raise several intriguing questions, and are considered, in some places like Malta, something of a mystery. The existence of similar structures in Terceira Island, Azores, Portugal, being located in the middle of Atlantic Ocean, renders the subject even more perplexing. Like in Malta, the Azorean tracks or "cart-ruts" remain an enigma because they have not been satisfactorily explained by the ethnographic or archaeological works, at least so far. Only Mendes et al. (2011) made a study (ethnographic study) on the Azorean cart-ruts.

The most consensual ethnographic explanation for the Azorean tracks attributes their origin to the Portuguese settlement of the islands in the $15^{\text {th }}$ century, whereas others claim that their formation must have taken place during the $17^{\text {th }}$ and $18^{\text {th }}$ centuries (Borges, 2011). The presence of parallel tracks in all the 
nine Azores Islands is explained, by the locals, in a similar fashion. As a consequence, the Azorean tracks have been largely marginalized in the archaeological and geographical literature: they have never been the subject of an island-wide scientific investigation. For example, to show that, the first cart-ruts of Corvo Island (the smallest island of the Azores) were discovered and reported only in November of 2017 on a local newspaper (Diário Insular, 2017).

As mentioned before, first historical mention of the Terceira Island cart-ruts was made by Francisco Ferreira Drummond in the $19^{\text {th }}$ century, who provides the following observation on Terceira Island, which was initially called Jesus Island:

"We observe thus, that the first track for going into the woods was made only in the decade of 1500, and probably not to find timber or wood, for all this existed in the same inhabited places, besides the fact that the village was too small, and the difficulty associated with the pathways and the distance of three leagues [20 km] was too great an obstacle, those vestiges could not be found at first sight, nor could those cart tracks be done during the $17^{\text {th }}$ and $18^{\text {th }}$ centuries, during which there was no need of bringing those carts into the high woods, where the vestiges mentioned are. An obstacle may be raised against this observation, which is reasonable at first sight; this is: that only there we find them, and not elsewhere. To which we may answer that in some excavations signs of older buildings were found, as other things which cause perplexity. Thus the Jesus Island seems to have been inhabited by another people (back in very early ages)" (Drummond, 1859: pp. 20-21).

The archaeologist Borges (2011: pp. 4-5) argues that the ox-cart grooves found in the Azores are a proof of the continued use of technologies and traditions, in his words "brought from Europe by the first settlers". He argued that "these technologies evolved very little until the 1970's, when the roads used by oxcarts were abandoned or modernized to be used by automobiles with rubber tires". He also mention that "in fact the oxcart grooves are seen everywhere as marks left on the ground by the ox-carts over decades and centuries, and even millennia of use, as on some Roman roads". The intriguing nature of these marks, leads a divergence between opinions that characterises the literature discussing the use of cart-ruts.

In 1836, when Charles Darwin visited Terceira Island, he passed by the cart-ruts with the name of "Passagem das Bestas" (The Passage of the Beasts):

"I noticed in several places, from the long traffic of bullock waggons [sic], that the solid lava which formed in parts the road, was worn into ruts of the depth of twelve inches. This circumstance has been noticed with surprise in the ancient pavement of Pompeii, as not occurring in any of the present towns of Italy. At this place the wheels have a tire surmounted by singularly large knobs; perhaps the old Roman wheels were thus furnished." (in Armstrong, 1992).

It is important to note, however, that Darwin's writing suggests that he is thinking of an analogy between Roman cars and the $19^{\text {th }}$ century Portuguese cars 
he observed in Terceira Island (Martins, 2015: p. 193).

For a long period “The Passage of the Beasts" was forgotten. In the 1988 these cart-ruts were rediscovered by José Maria Botelho, a member of the local speleological association. The cart-ruts were completely covered by local vegetation (Barcelos, 2011). When we looking to the "crossings" from one rut to another, the ethnographical explanation of "The Passage of the Beasts" present a navigational nightmare for waggon drivers that would attempt to use them. Is not easy to imagine how such manoeuvres have been repeated, if we assume that the ruts were made with repeated passes. Borges (2011) believes that the depth and the quantity of the ox-cart grooves in the place, which are adjacent and cross and link with each other, constitutes a proof of the strong industrial activity in Terceira Island, both in what concerns the number of carts and the volume of firewood transported each year. But such a conjecture is not supported by historical or biological facts (poor soil at the site for wood production and at the timberline transition) or with a clear connection between this place and the main town of Terceira Island.

Another speculation that enhances further confusion of the cart-ruts of Terceira Island and also on another Azorean Islands is the characteristics of the tracks. The depth and size of the cuts differ substantially, and some are shaped as a "U", others take the form of a "V" or "W" and others quasi-U or rectangular shapes. At Porto Martins village (Terceira Island) the ruts tend to suddenly disappear at the edge of the island and seem to continue under the sea water.

\section{Comparing Cart-Ruts Hypothesis}

Until now the cart-ruts have remained an unsolved puzzle to all scholars who tried to describe their functionalities. All proposed theories are based on previous assumptions and limited evidence. Until now no one has tried to see if the Azorean cart-ruts fit well with the hypotheses explored on other places. We believe that this is the first attempt.

Cart-ruts are not unique to Terceira Island or indeed the Azores Islands; they can also be found in Malta (Mottershead, Pearson, \& Schaefer, 2008) or Switzerland, France and Italy (Schneider, 2001) among other countries. The most famous ancient cart-tracks area in the world is Malta's cart-ruts and there is no direct clear evidence that they are manmade, because when we observe the rut walls no evidence, or even hint, of human activity in excavating ruts, such as might be provided by pick marks (Mottershead et al., 2008). But other countries with cart-ruts do seem to have supporting evidence for manmade cart-ruts, such as Italy or Switzerland, at least in the Roman period (Hughes, 1999; Schneider, 2001). For Malta, only Dawkins (1918) considered the cart-ruts entirely natural features and of no archaeological significance. The cart-ruts of Pompeii are clearly manmade and the most obvious features are, according to Poehler (2008) and Schneider (2001), wheel ruts left in the paving stones. Here we can clearly assume that the "Passage of the Beasts" car-ruts were man-made because the 
archaeological context in which they were found includes man-made bowls.

Despite the renewed interdisciplinary academic interest in Maltese prehistory, the spatial and chronological dimensions of the ancient track network (the most studied cart-ruts in the world) were not addressed until 2000. A study that intended to address the significance of cart-ruts in ancient landscapes of Malta was funded by the European Culture 2000 programme (Department of Information-Malta, 2005). This led to the most comprehensive explanation of cart-ruts thus far published, and its inception resulted into a previous assumed mind-set hypothesis of wheeled-vehicle tracks, like for the Azorean cart-ruts. Even now, there is no comprehensive explanation of animal traction pulling carts or waggons through the Maltese cart-ruts (Sagona, 2015) and also this could be said for the Azorean cart-ruts.

Assuming for the Azorean cart-ruts the same complexity of the dating processes of the Maltese cart-ruts and their functionalities, this work will be not centred on the discussion of the nature of the Azorean cart-ruts. Rather, it merely tries to establish a chronological interval for their construction or appearance. But it was clear from the beginning that it would be impossible to avoid comparisons with the Maltese cart-ruts, not least when considering dating methods.

Bugeja (2001), made a revision of the different dating methods of Maltese cart-ruts, and points out the main limitations of these investigations. Almost of the works mentioned by this author point to the Maltese cart-ruts as a transport system of soil, stones or goods, but it is difficult to make a clear connection between the ruts and the transported or explored material. The entire hypothesis points out to the transport of heavy material trough the ruts. Similarly, no old quarries near the "The Passage of the Beasts" were found and the hypothesis of soil transport is inappropriate because the area has a poor and thin layer of soil from volcanic origin. If we assume the use of the ruts for transport of any kind of goods, the only coherent hypothesis will be wood. If wood were carried out off the Guilherme Moniz Caldera (the place where The Passage of the Beasts is installed), a huge amount must have been transported and that implies probably exportation.

A possible explanation could be the production of furniture, infrastructure and ships in Terceira Island after Portuguese arrival, much of which exported, given how appreciated the island's cedar (Juniperus brevifolia) was, even if, for this hypothesis to work, the quantity of wood transported would have to surpass whatever is conceivably given the existing historical economic analysis or historical records. Azorean cedar is not present at the place where the studied cart-ruts are. This could be also associated to ecological constrains that made the Juniperus brevifolia (Seub.) Antoine appear especially in mountainous areas above $500 \mathrm{~m}$ (Elias \& Silva, 2008). The mean altitude of the Guilherme Moniz caldera is close to $500 \mathrm{~m}$ and is a flattened area. These two facts weaken the previous hypothesis, if the landscape has been preserved intact since Portuguese colonisation. It is possible that the original vegetation cover has been partially destroyed by human activity during historical times. In the past, the Juniperus 
brevifolia distribution on Terceira Island could be different from today. Today this species mostly occurs at higher elevations, but evidence from historical records (Frutuoso, 1873) suggests it grew at much lower elevations in the past. This is confirmed by pollen evidence from low-elevation lakes on São Miguel Island (Rull et al., 2017). This also means that we are not able to reject the hypothesis of the "Passage of the Beasts" cart-ruts being used for wood transport.

\section{4. "The Passage of the Beasts" Cart-Ruts Main Characteristics}

In recent years (2015-2016), the City Hall of Angra do Heroísmo, the main town of Terceira Island, have decided to remove the vegetation inside the ruts of The Passage of the Beasts. These cleaning activities became an opportunity to study the "Passage of the Beasts" cart-ruts system, because parts of them were covered, at least, by a tinny layer of soil. To understand the place it was important to know their geological context, because the geologic past offers a sobering perspective on the rates of human resource use and environmental degradation or space occupation. Figure 1 shows the location map of where the cart-ruts occur in relation to volcanoes of the island.

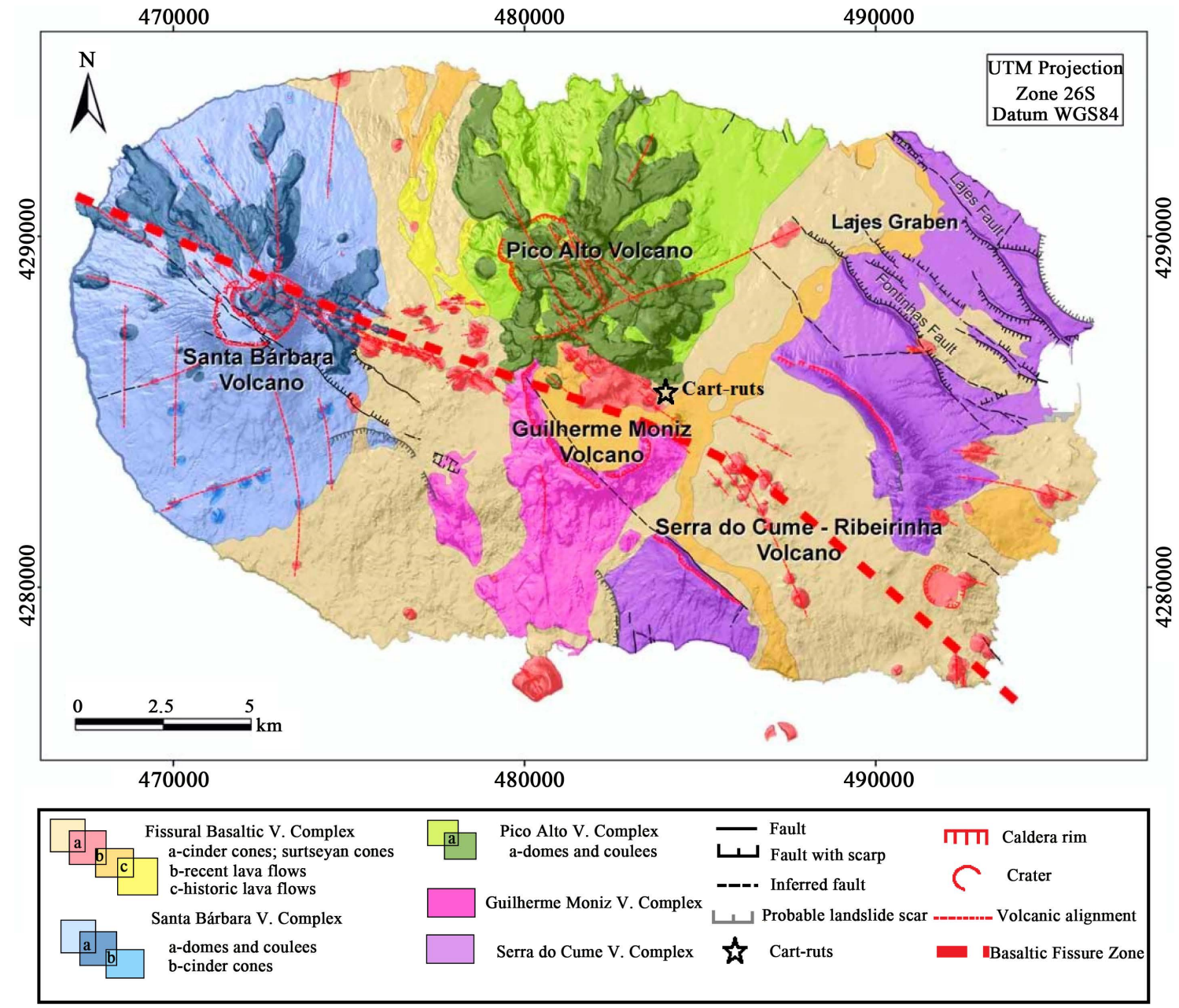

Figure 1. Simplified geologic map of Terceira Island (adapted from Quartau et al., 2014). 
Terceira Island grows and evolves by the action of several geological processes. Their present-day morphology is the result of the activity of volcanic, erosional, depositional, tectonic, isostatic, eustatic, and mass-wasting processes (Ramalho et al., 2013).

"The Passage of the Beasts" is installed on the Guilherme Moniz strato-volcano with 270,000 years (Calvert et al., 2006) built on the western flank of the Serra do Cume-Ribeirinha shield volcano and is predominantly composed of trachyte domes and lava flows, with minor associated pyroclastic deposits (Quartau et al., 2014).

The extension of the parallel ruts thus found was $213 \mathrm{~m}$. The deepest groove found measures up to $32 \mathrm{~cm}$ (Resendes \& Moniz, 2015). Another cleaning of The Passage of the Beasts ruts was undertaken in 2017, and the extension of the ruts is much greater than thought. At this moment this extension of the ruts are greater than $300 \mathrm{~m}$, and the deepest groove found measured $40 \mathrm{~cm}$. The degree of rut incision varies considerably from traces $(3 \mathrm{~cm})$ to $40 \mathrm{~cm}$. The ruts show a persistent rounded $\mathrm{U}$-shaped profile, exhibiting a more flattish shape only where duplication or crossings has occurred (see Figure 2 and Figure 3).

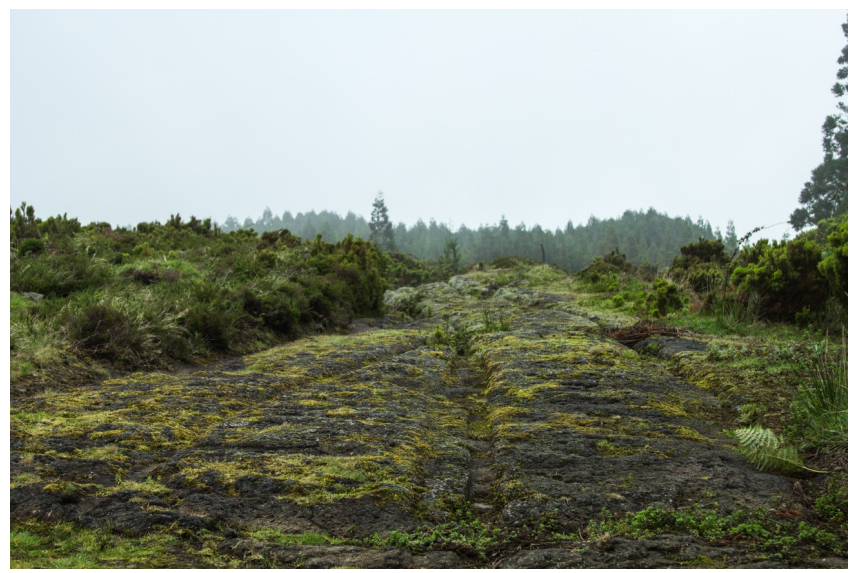

Figure 2. Rut shape as crossings (coordinates: $38^{\circ} 42^{\prime} 32^{\prime \prime} \mathrm{N} 27^{\circ} 10^{\prime} 58^{\prime \prime} \mathrm{W}$ ).

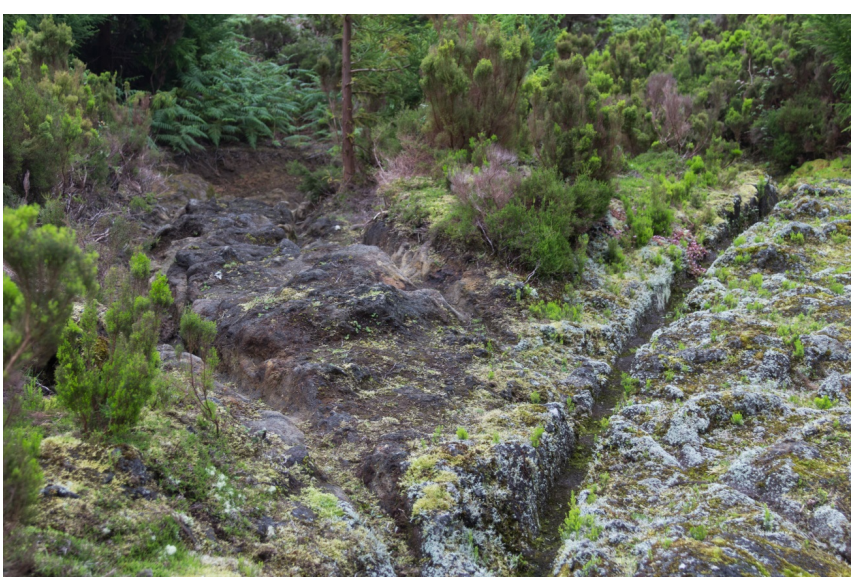

Figure 3. Ruts deep and crossings (average $30 \mathrm{~cm}$ depth). The grooves at the end of the left side where filled with volcanic ashes. 
The gauge characteristics of the tracks vary from $1.1 \mathrm{~m}$ to $1.4 \mathrm{~m}$, averaging $1.14 \mathrm{~m}$. When we compare these measures with those ones reported by Hughes (1999) for the Maltese cart-ruts, the distances between paired ruts are shorter but the depth of the tracks is similar. When we measure the distance between ruts along the main trail, it is possible identify at least five distinct distances (see Figure 4):

1) Ten measurements between parallel ruts with $1.1 \mathrm{~m}$ which constitute the statistical mode of the observed measurements,

2) Four measurements under the measure of $1.1 \mathrm{~m}(1.07 \mathrm{~m})$ which constitute the minimum of the distance between parallel tracks measurements but with a standard deviation (a measure of the data variability) able to put them in the same group of the $1.1 \mathrm{~m}$ cluster,

3) Seven measurements with $1.15 \mathrm{~m}$, statistically different from the ones above mentioned (even if we consider the standard deviation),

4) One measurement with $1.28 \mathrm{~m}$,

5) One measurement with $1.38 \mathrm{~m}$ which constitutes the maximum distance between parallel ruts.

The maximum distance between ruts was observed near a crossing with an $\mathrm{X}$ shape with well-defined triangles. Looking from above, this resembles intersecting railway lines, with their turns and junctions in several route directions (see Figure 5).

The $1.28 \mathrm{~m}$ distance between parallel ruts was observed after a fracture of the bed rock, probably associated with non-historical seismic activity. At certain places of "The Passage of the Beasts" we find a strong gradient between the two rails. The only explanation for the fracture here is that the rock had been moved by seismic activity after the rails were used, but the seismic activity is not able to explain the enlargement of the distance between parallel ruts.

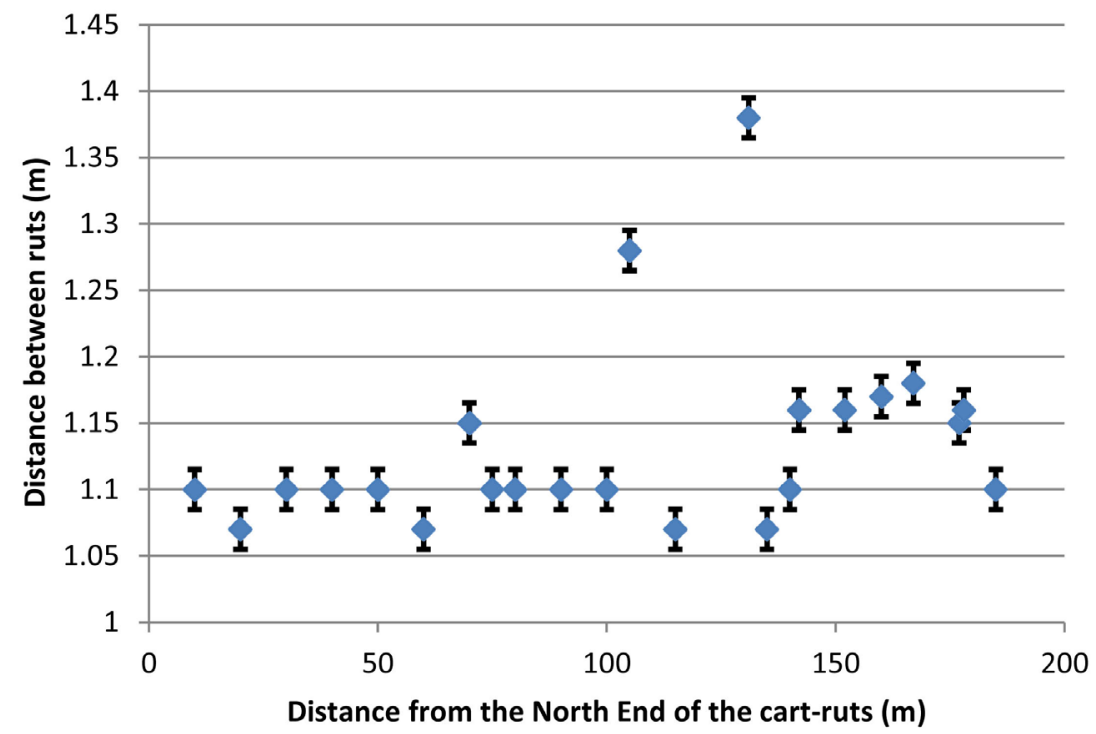

Figure 4. Pattern of the distance between parallel ruts at "The Passage of the Beasts" in the main cart-ruts. The black line represents the standard deviation. 


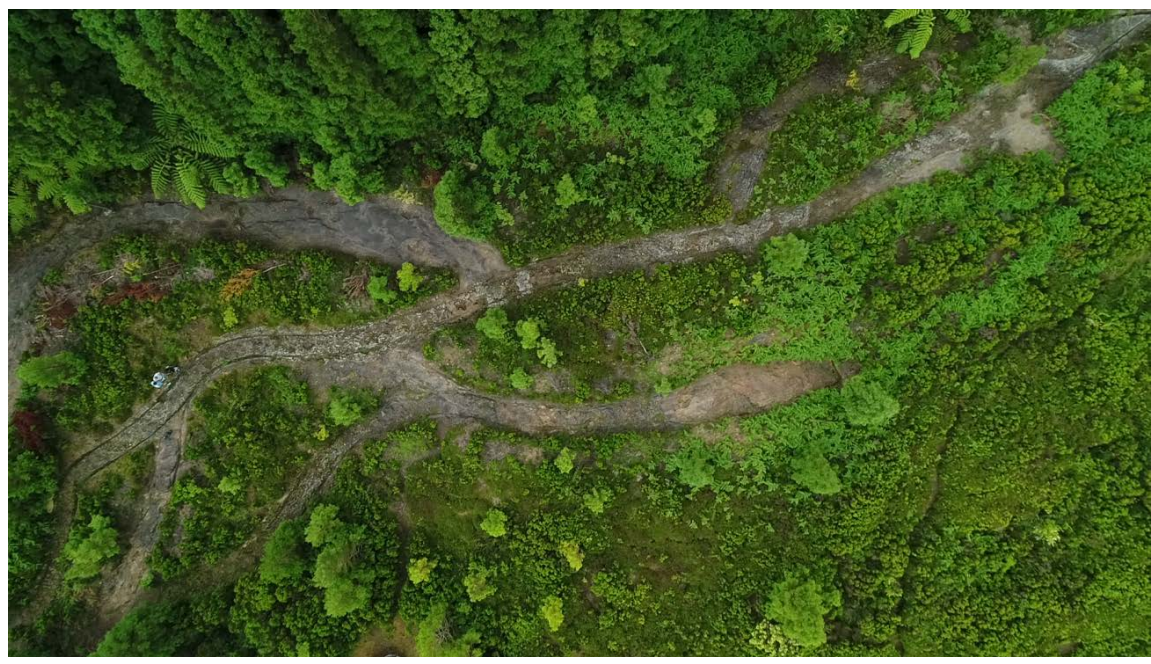

Figure 5. Aerial view of The Passage of the Beasts with few unearthed branches. The image of a man standing up there serves as scale (Assigned to this work from Paulo Pereira, 2017).

The statistical distribution of the measurements is not Normal and tends to fit a Poisson distribution. When we remove the extreme high values (outliers) and test our data again we are then close to the Normal distribution. If we remove the outliers, is not possible to explain the distance between parallel ruts by the use of ox-carts over decades because the axis of the oxcarts were not extensible or were not made with the same and precise standards during decades or centuries. On other hand, if we attend to the adversity of the steep slopes of "The Passage of the Beasts" and to the surface irregularity of the bedrock we conclude that these cart-ruts were not possibly used by oxen, horses or donkeys (animals with hooves): only humans could have used them. A good correlation between the width of the left side groove and the width of the right side groove seems to appear in the central cart-ruts of "The Passage of the Beasts" (see Figure 6) with a similar average width $(18.1 \mathrm{~cm}$ and $18.3 \mathrm{~cm}$ respectively). This correlation is not related to local variations in the hardness of the rock because the incisions are observed in the same lava flow.

Like in Figure 4, an outlier appears connected with the observed fracture. Both statistical distributions are Normal, even we include the outlier. If we exclude the outlier we are able to explain the widths of both grooves because, when one wheel of a car, or a fix device, slides to the left side, the other wheel or extreme of the device slides into the same direction. This result seems to contradict the conclusions about the distance between parallel grooves along the main trail, but it is clear that we have four distinct distance between grooves, with the same sliding effects (see Figure 7) when we remove the outliers.

To explain the observed trends we must admit that the axis of the device that produced the grooves varied or the bed rock has expanded or has compressed through time. We can argue that this suggests an unknown seismic activity on the site, but the fact that the grooves are carved in rigid volcanic rock make this explanation unlikely. 


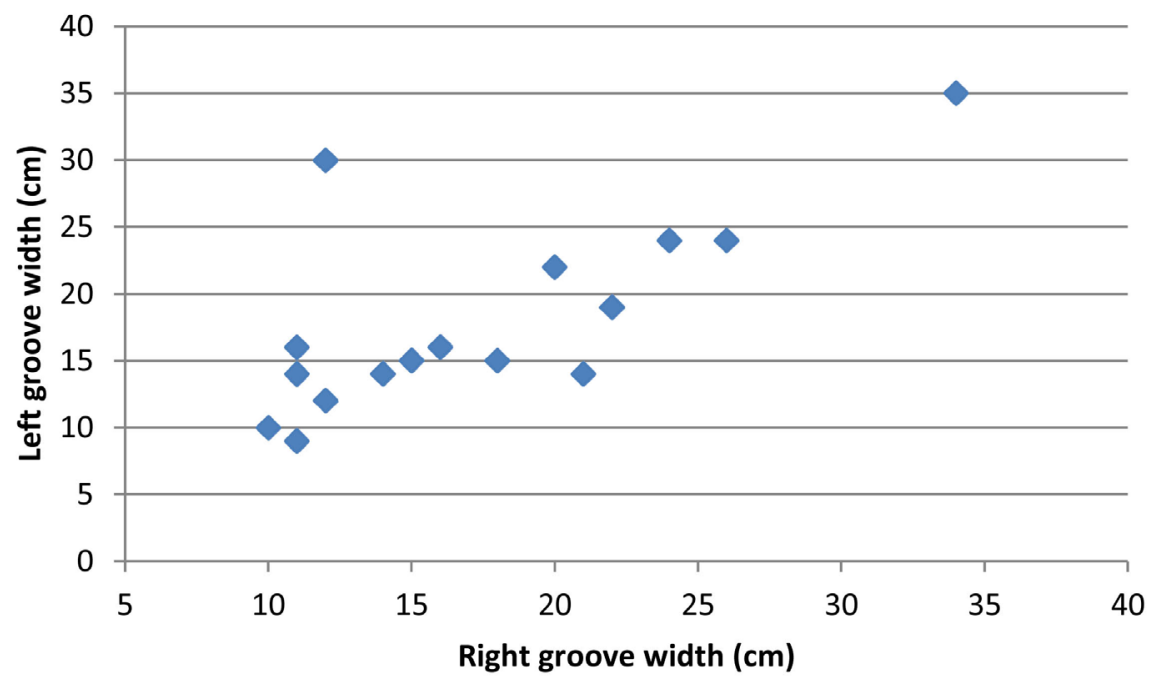

Figure 6. Correlation between the widths of the right and the left grooves.

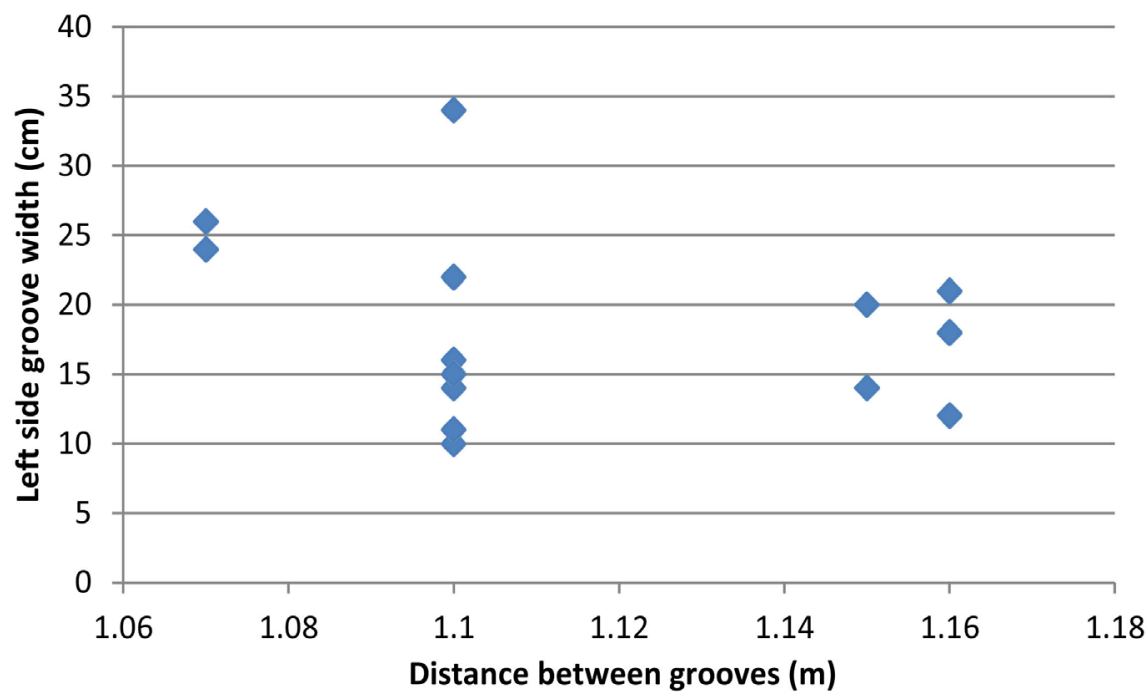

Figure 7. Distance between parallel grooves versus width of the left side groove.

Only a few places of the studied cart-ruts appear to have a direct correspondence between the depth of the right and the depth of the left grooves. Globally, no correlation was found between the depths of the grooves along the main trail. Both depth data distributions are Normal and are not related with a chemical heterogeneity of the stone or different slopes of the bed rock where the ruts are. Several branches on the main cart-ruts were found, which means, ruts adjacent to the main paired tracks, with crosses and links with each other. It is not easy to explain these derivations that in some cases turn up again.

\section{Dating the Cart-Ruts of "The Passage of the Beasts"}

The tracks of "The Passage of the Beasts" had a tendency to run downhill with a gradual slope, far away from the modern road, and parallel to a water line. The closest known historical road coincides with the modern road. 
During the recent cleaning and unearthing of the tracks, new connections between ruts were perceived as it was inferred that volcanic deposits obscured earlier ruts. Until now, five lateral trails of the "The Passage of the Beasts" were fully covered by volcanic ash (see Figure 8).

Terceira Island presents active volcanism and a significant seismic activity which can explain the observed fracturing of the bed rock.

Since Terceira Island settlement in the $15^{\text {th }}$ century, only one volcanic eruption took place on land in 1761. This volcanic eruption were not able to cover "The Passage of the Beasts" cart-ruts because was an aa-type lava flow, not present in this place, with an average thickness of about 3 meters, strongly controlled by the paleomorphology of the area (Nunes et al., 2014). Before that time we find several candidate eruptions, the most recent related with Pico Alto Volcanic Complex: a tightly spaced cluster of trachyte domes and short flows, which is a younger part of Guilherme Moniz Volcano. Stratigraphic studies and radiocarbon analysis suggest that the Pico Alto eruptions occurred at 1000 years BP (Self \& Gun, 1976; Calvert et al., 2006; Nunes et al., 2014; Quartau et al., 2014). The Pico Alto strato-volcano was built on the northern flank of Guilherme Moniz Volcano. It has a radius of $6 \mathrm{~km}$ and culminates at an elevation of $808 \mathrm{~m}$, with a $3.5 \mathrm{~km}$ wide summit caldera (Quartau et al., 2014).

The tracks of "The Passage of the Beasts" were incised on a lava flow on Guilherme Moniz Caldera. Guilherme Moniz Volcano has developed with the initial formation of an imposing shield volcano. Subsequently, it evolved into a more explosive character, culminating in the caldera collapse, which occurred less than about 270 thousand years ago (Gertisser et al., 2010). If the volcanic ashes that were found covering "The Passage of the Beasts" cart-ruts comes from an

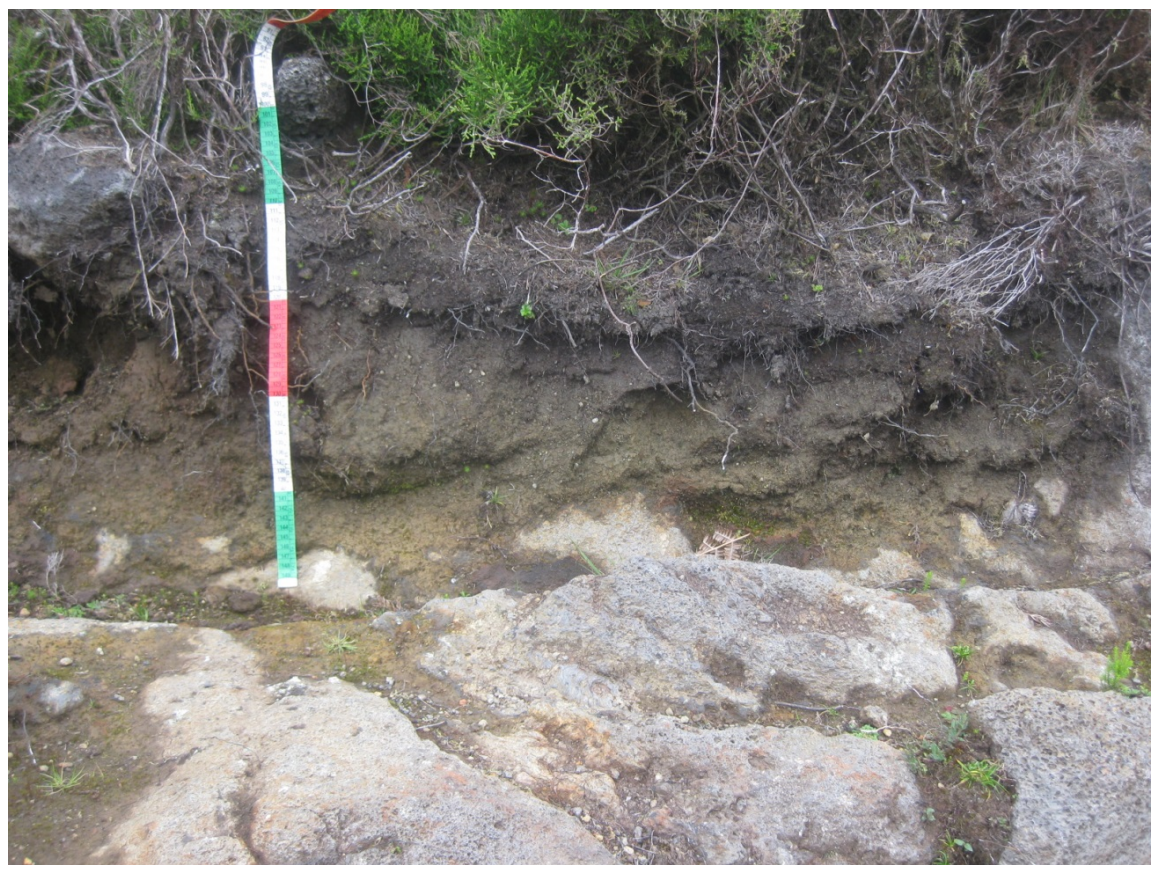

Figure 8. Unearthed groove filled above with volcanic ashes. 
eruption of Pico Alto, we can date them as being, at least, 1000 years old. We can have also others volcanic eruptions as candidates, to cover the observed car-ruts, such as the lava flow come from Algar do Carvão eruptions, that according to Calvert et al. (2006) are dated between 1880 years BP and 10,090 years BP. Pico Alto eruption seems to be the youngest candidate if the observed ashes comes from a volcanic eruption rather than deposited by erosion of older pyroclastic deposits or an unknown human activity on the area.

According to Self and Gunn (1976) we have at Guilherme Moniz Caldera a chaotic assemblage of comendite and pantellerite domes and coulées largely infilling this caldera. The Caldera floor is covered by young basalts erupted from the adjacent fissure zone.

The pyroclastic flows erupted from Pico Alto, in the central part of the Terceira Island, generally followed topographic depressions towards the North and South coasts. The pyroclastic flows from Pico Alto travelled over flat interfluve surfaces where they left thin deposits (Self et al., 2005).

"The Passage of the Beasts" cart-ruts are clearly in an interfluve area at the middle of two actual deepest water-lines.

As can be perceived, on the Figure 9, part of "The Passage of the Beasts" cart-ruts was covered by a pyroclastic flow. We can clearly see that in other branches of the cart-ruts were we found pyroclastic accumulations with $50 \mathrm{~cm}$ to $2 \mathrm{~m}$ of thickness. The pyroclasts found inside the cart-ruts varies from agglomerate to very fine ashes and tuffs.

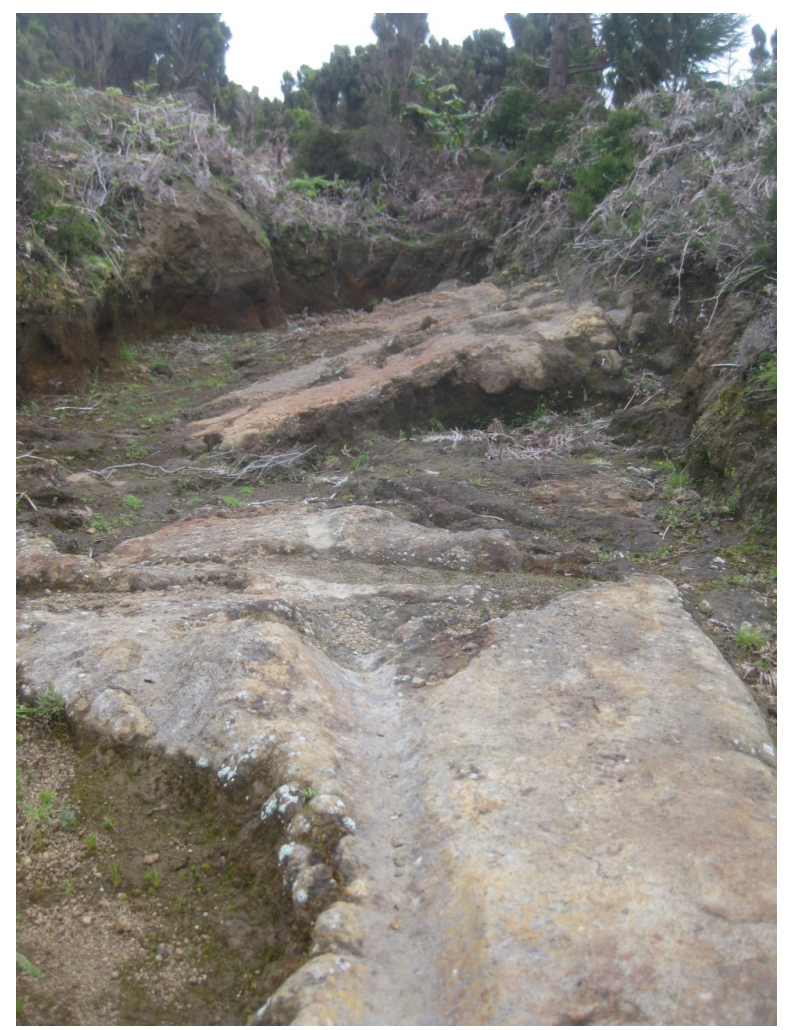

Figure 9. Branch of unearthed cart-ruts, with pyroclasts in front and lateral sides. 
We made a terrain profile (Figure 10) in order to see the changes on the cart-ruts slopes and their possible relationship with general pattern of the soil horizons, because, despite no historical eruptions being known in this area, the volcano's eruptive activity of Pico Alto has been quite recent, occurring the last one in about 1000 years BP, according to estimates of Calvert et al. (2006) and Self and Gunn (1976). Given the uncertainty regarding to the time when the ashes covered the cart-ruts, it was important to study the configuration of the volcanic material laid on the top of them.

The obtained profiles 3 and 7, which are at the same altitude, were located on two distinct branches of "The Passage of the Beasts". All the observed cart-rut branches of this system are connected with the main central path of "The Passage of the Beasts", as can be seen in the Figure 5.

On Figure 11 it is presented the found horizons in the different profiles, which varies from an organic soil (O Horizon) to basaltic rock/cart-ruts (R Horizon) for all the sampled sites.

The thickness of the "cart-ruts layer" corresponds to the groove deepness of the cart-ruts at each sampled sites. In all the sampled places, except in the first point, the grooves were filled with a Birm Horizon (a cemented Horizon or placic Horizon) above a small layer of fine pumice.

Above the Birm Horizon it was found, except in site 1 and 7, a layer of fine pumice. In the site 1 (the less extended and variable profile) it was found basaltic lapilli under a Bt Horizon (probably a transformation of the C Horizon with clay accumulation indicated by finer soil textures), and in site 7 , the fine pumice layer was above a layer of trachytic lapilli.

Sites 2, 6 and 7 present a reddish brown Bir Horizon on the top of the pumice layer. The site 2 also has a Bir Horizon on the top of a Bt Horizon, and site 7 has a Bir Horizon in the middle of a volcanic tuff layer. These Bir Horizons reveal the stability of the above volcanic material layers.

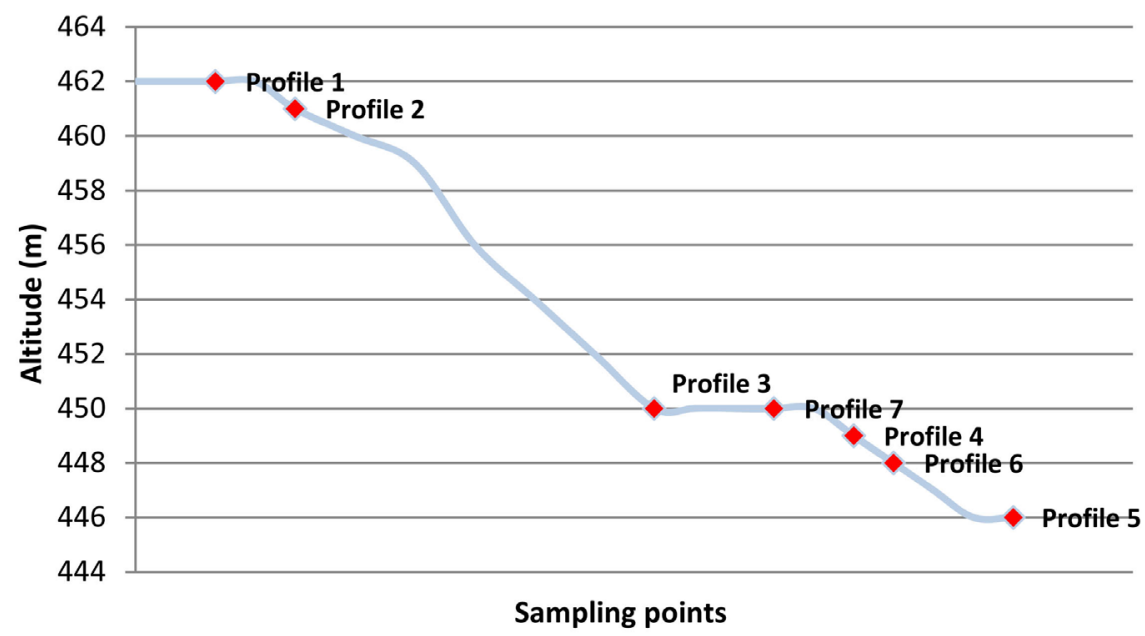

Figure 10. Altitude of the sampling points to determinate the general pattern of the horizons. 


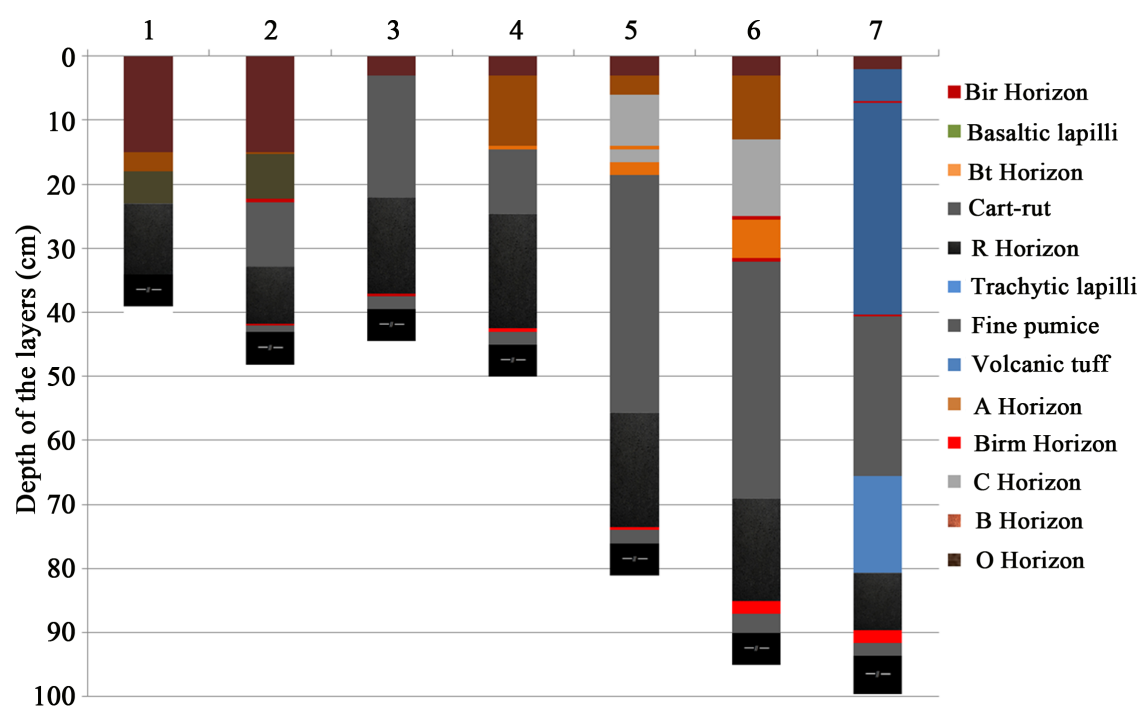

Figure 11. Distinct layers covering the grooves of "The Beast Passage" according the USDA soil taxonomy.

The same temporal stability seems to be present at sampled site 7, because the volcanic tuff layer, above the fine pumice layer, seems to result from the compaction of the ash onto a solid rock by consolidation. The consolidation involves a decrease in the water content of the saturated soil without replacement of water by air. In general this is the process in which reduction in the volume takes place by expulsion of water under long term static loads. This can explain, at site 7 , the existence of a pumice layer (less consolidated) under a volcanic tuff layer.

Sites 2, 4, 5 and 6 present small Bt Horizons that only show clay skins on vertical ped surfaces.

An A Horizon was present on sites 1, 2, 4, 5 and 6. Taking into account all the results, the thickness of the A Horizons seems to correlate negatively with the thickness of the O Horizons.

Globally, the seven profiles seem to have different pedogenic processes related with the natural organization of particles that forms discrete units separated by pores or voids. The observed layers also seemed dependent of the vertical water infiltration and points to a long temporal stability, which means unchanging horizons in quantity, quality or physical conditions. For other hand, the studied area has soils containing very different horizons whenever compared to an "ideal" soil. When we look to site 7, located few meters away from site 3, the horizons seems to have different origins with volcanic ash consolidated on site 7 and not at site 3. This could be associated to the fact that the area is a chaotic assemblage of domes and coulées as mentioned by Self and Gunn (1976) or to a heterogenic ashes dispersion influenced by the wind during eruptions, given an enormous heterogeneity to the terrain.

The pumice deposits found at the studied sites are compatible with last largest sub-plinian pumice deposits erupted from Pico Alto, and also compatible, with the isopach map of pumice deposits for such 1000 years eruption, produced by 
Self (1976).

No older soils were found on Guilherme Moniz Caldera, or around the sampled sites, able to remobilized carbon to these places from more developed surrounding soils. No paleosols interbedded within tephra layers were observed. All this seems to mean that either the pedogenesis was incipient because of the lack of time between volcanic episodes or because of the unfavourable morphological position of the deposits, or, being well developed, the upper horizon may have been eroded. If an erosion surface was not observed to truncate a placic horizon, the dating obtained through him, although it represents rigorously only a terminus post quem, must be close to the real age of the volcanic ashes above this horizon.

To have certainty about the age of the materials above the cart-ruts, a blackish-brownish layer (placic Horizon) formed inside the grooves were analysed. The studied layer was cemented mostly by iron, manganese and organic matter (see Figure 12).

The layer was analysed by a soil specialist (Professor João Madruga, co-author of this work) from the University of the Azores and it was classified as a placic horizon.

The placic horizon generally has a thickness between $2 \mathrm{~mm}$ and $10 \mathrm{~mm}$ (USDA, 1999). The placic found onto the cart-ruts has a thickness between 2 $\mathrm{mm}$ and $3 \mathrm{~mm}$.

Most placic horizons occur in areas of moist climates with low evapotranspiration as in this case. The annual average precipitation at the cart-ruts place round the $2800 \mathrm{~mm} /$ year whereas the evapotranspiration is about $666 \mathrm{~mm} /$ year (Novo, 2009).

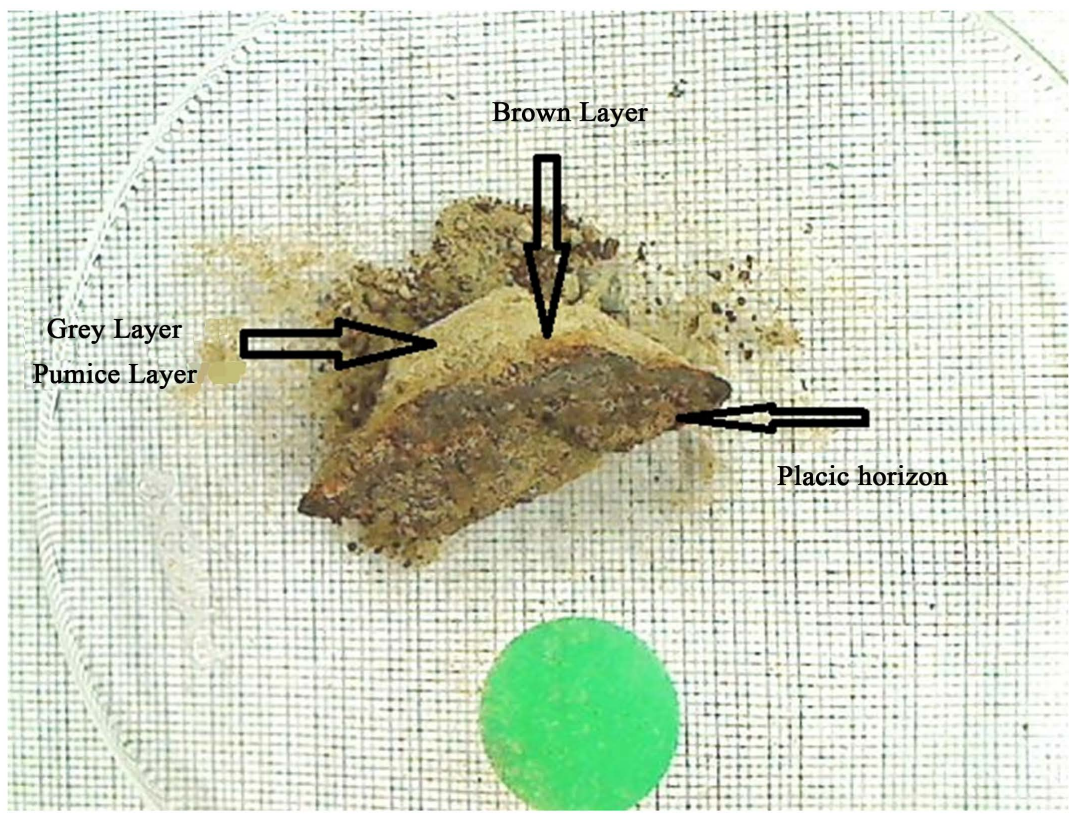

Figure 12. The pumice layer was inside a groove at site 6 , and the placic horizon is above the brown iron rich layer. 
Research on placic horizons genesis suggests that the iron is reduced and mobilized in the horizon surface, than oxidized and precipitated in the B horizon, where it can adsorb soluble organic matter (USDA, 1999). The placic horizons form in material with a variety of textures ranging from sands or volcanic ashes to clays. In the British Isles the placic Horizons occur under peat-forming ericaceous or grassy semi natural vegetation, which was a 3000 years look-a-like forest that was subjected to periodic burns (USDA, 1999). Similarly, the Guilherme Moniz Caldera vegetation is composed essentially by native vegetation of Erica azorica Hochst. ex Seub. (ericaceous) and sphagnum peat (Sphagnum sp). No traces of fire near the area of cart-ruts were observed.

If the information extracted from geological data with pedological data (volcanic ashes origin and placic horizon genesis) is compared, we are able to point out a possible chronology for "The Passage of the Beasts" cart-ruts: They are older than 1000 years.

In order to cross this chronology with further dating methods, a sample of placic horizon (see Figure 12), collected inside a groove of one unearthed cart-rut was taken for Accelerator Mass Spectrometry (AMS) dating. The sample was sieved through a 180 micrometre sieve. After the treatment of that sediment with acid, it was analysed at Beta Analytic Lab (USA). The AMS radiocarbon dates were calibrated using IntCal13 and Marine13 radiocarbon age calibration curves 0 - 50,000 years cal BP (Reimer et al., 2013).

At a first glance, the material caught in the sieve did not appear to be organic due to the fact of having large amount of iron and manganese. The factors influencing the formation of these cemented horizons are poorly understood, and it was assumed that the sample had also organic matter. The sample was than treated with a stronger acid to break up and dissolve the iron and the emitted $\mathrm{CO}_{2}$ recovered. The conventional radiocarbon age obtained was $920 \pm 30$ years BP (Beta Analytic code-460931). The calibrated result (95\% probability) was Cal AD 1025 to 1190 .

In wet or flood plains, a dated sample may be composed of carbon from several sources, which may have been younger or older than the level it was deposited in, but normally younger pyroclastic products (pumice falls associated with pyroclastic surges, pumice flows or volcanic breccias) cover the older deposits. It is also possible to have run water through the impermeable grooves, in the bed rock, which can bring in carbon of younger ages. Thus, as far as we could see at different profiles, and taking into account the cart-ruts slopes, the cavities on Guilherme Moniz Caldera and the isopachs of the pumice dispersions of the $\mathrm{Pi}$ co Alto eruptions, any ${ }^{14} \mathrm{C}$ ages from such placic horizons could simply be seen as a minimum age (terminus post quem) for the grooves. We have no any kind of evidence of water re-deposition of ashes or erosion on the different horizons, except on the topsoil.

When we look to the dating processes approaches presented in this work (historical, volcanic, placic genesis and carbon dating), we have a minimum objective date for "The Passage of the Beasts" cart-ruts: 920 years ${ }^{14} \mathrm{C} \mathrm{BP}$ 
(1025-1190 cal AD). This result is compatible with the estimated of Calvert et al. (2006) for the youngest eruption of Pico Alto, that took place 1000 years BP (500 years before the Portuguese arrival) and with the time it takes for a placic horizon formation.

\section{Conclusion}

Comparing historical references with geological, pedologic data and physical analysis we can find evidence that suggests we could push back the chronology of "The Passage of the Beasts" cart-ruts, at least, for 1000 years B.P..

If we assume 1000 years old for "The Passage of the Beasts" construction, these cart-ruts do not seem to be Roman or Portuguese. We only can say that they are likely to be pre-Portuguese.

The topographic parameters of "The Passage of the Beasts" cart-ruts on Terceira Island, Azores, Portugal, clearly show that the grooves were not made as water ways or as an old system for water to flow to certain spots. Taking into account the humidity and rain patterns of the island and soil profile of the Guilherme Moniz Caldera (little top soil), no irrigations system was needed for agricultural production at that place (assuming that the climate has never changed, being the same described by Gaspar Frutuoso (1873) when the first settlers arrived to the Azores). These grooves are parallel to a natural water line and have a water catchment nearby. It seems unlikely that these grooves were used for irrigation, drainage or agriculture.

The irregularity of the surface of the bed rock, where the ruts are made, points towards an explanation other than the extensive use of ox-carts. It seems difficult for animals with hooves, like oxen, horses or donkeys to move across the irregular shape of the bed rock with the observed slopes. At the Azores, traditionally, the ox-carts were pulled by two oxen, but at this place part of the cart-ruts system is embedded in the ground and only permits the passage of a lonely animal.

The presented chronology for the Passage of the Beasts is consistent with previous chronologies that point towards human presence in Terceira Island in or before the $11^{\text {th }}$ century and also contributes towards the emerging literature on pre-Portuguese presence in the Azores Islands.

Furthermore, our analysis seems to confirm an important observation made by Drummond (1859) the most complete and authoritative historian of Terceira Island, thus addressing an important hypothesis within the Azorean historiography that had not been subject to scientific testing so far. This enables integration between scientific and historiographical elements that provides a fruitful route for future investigation, even if much further work is still necessary in order to identify a clear archaeological context for further inferences on which specific culture may have existed in the Azores Islands before Portuguese arrival.

\section{Acknowledgements}

This research was funded by the (IITAA) Institute of Investigation on Agro- 
nomic and Environmental Technologies of the Azores from the University of the Azores.

\section{Conflicts of Interest}

The authors declare no conflicts of interest regarding the publication of this paper.

\section{References}

Armstrong, P. (1992). Charles Darwin's Last Island: Terceira, Azores, 1836. Geowest, 27, $1-61$.

Barcelos, O. (2011). Tearing Secrets from the Land. In A. Mendes, O. Barcelos, L. Barcelos, L. Duarte, \& A. Araújo (Eds.), The Passage of the Beasts (pp. 6-12). Ponta Delgada: Nova Gráfica.

Borges, L. (2011). The Oxcart Grooves. In A. Mendes, O. Barcelos, L. Barcelos, L. Duarte, \& A. Araújo (Eds.), The Passage of the Beasts (pp. 4-5). Ponta Delgada: Nova Gráfica.

Bugeja, A. (2001). Methods of Date Assignment for Cart-Ruts in the Maltese Islands: Discussing Relationships with Bronze Age Fortified Settlements on Promontories. The Oracle, 2, 23-35.

Calvert, A. T., Moore, R., McGeehin, J., \& Rodrigues da Silva, A. (2006). Volcanic History and ${ }^{40} \mathrm{Ar} /{ }^{39} \mathrm{Ar}$ and ${ }^{14} \mathrm{C}$ Geochronology of Terceira Island, Azores, Portugal. Journal of Volcanology and Geothermal Research, 156, 103-115.

https://doi.org/10.1016/j.jvolgeores.2006.03.016

Centro de Estudos de Arqueologia Moderna (2017). Ilhas de Arqueologia. Episódio 1. 4 July 2017. RTP-Madeira. https://www.rtp.pt/play/p3639/e296851/ilhasdearqueologia

Dawkins, W. B. (1918). The Maltese Cart-Ruts. Man, 18, 87-89. https://doi.org/10.2307/2788611

Department of Information-Malta (2005). Malta's Participation in Eight Culture 2000 Projects. http://www.doi-archived.gov.mt/EN/press_releases/2004/01/pr0003.asp

Diário Insular (2017). Corvo esconde relheiras longas e intactas. DI, 22240, 8-9.

Drummond, F. (1859). Annaes da Ilha Terceira. Angra do Heroísmo: Tomo I. Camara Municipal D’Angra do Heroísmo-Typographia de M. J. P. Leal.

Elias, R., \& Silva, L. (2008). Juniperus brevifolia (Seub.) Antoine. In J. Martín, M. Arechavaleta, P. Borges, \& B. Faria (Eds.), Top 100 Las cien especies amenazadas prioritarias de gestión en la región europea biogeográfica de la Macaronesia (pp. 182-183). Gobierno de Canarias: Consejeria de Medio Ambiente y Ordenación Territorial.

Frutuoso, G. (1873). As Saudades da Terra (Vol. 1-6). Funchal: Typ. Funchalense.

Gabriel, S., Matias, M. L., \& Searle, J. (2013). Genetic Structure of House Mouse (Mus musculus Linnaeus 1758) Populations in the Atlantic Archipelago of the Azores: Colonization and Dispersal. Biological Journal of the Linnean Society, 108, 929-940. https://doi.org/10.1111/bij.12015

Gertisser, R., Self, S., Gaspar, J., Kelley, S., Pimentel, A., Eikenberg, S., Barry, T., Pacheco, J., Queiroz, G., \& Vespa, M. (2010). Ignimbrite Stratigraphy and Chronology on Terceira Island, Azores. In G. Groppelli, \& L. Viereck-Goette (Eds.), Stratigraphy and Geology of Volcanic Areas (pp. 133-154). GSA Special Papers 464.

https://doi.org/10.1130/2010.2464(07)

Hughes, K. (1999). Persistent Features from a Palaeo-Landscape: The Ancient Tracks of the Maltese Islands. The Geographical Journal, 165, 62-78. 
https://doi.org/10.2307/3060511

Martins, N. (2015). A Historiografia e o Povoamento da Ilha Terceira. Boletim do Instituto Histórico da Ilha Terceira, 73, 189-203.

Mendes, A., Barcelos, O., Barcelos, L., Duarte, L., \& Araújo, A. (2011). The Passage of the Beasts. Angra do Heroísmo: ART Associação Regional de Turismo.

Mottershead, D., Pearson, A., \& Schaefer, M. (2008). The Cart Ruts of Malta: An Applied Geomorphology Approach. Antiquity, 82, 1065-1079. https://doi.org/10.1017/S0003598X00097787

Novo, M. (2009). Alterações Climáticas e Seus Impactos nos Recursos Hídricos Subterrâneos em Ilhas de Pequena Dimensão: Caso de estudo: Açores-ilha Terceira. $\mathrm{PhD}$ Dissertation, Angra do Heroísmo: Universidade dos Açores.

Nunes, J. C., Calvert, A., Medeiros, S., Lima, E. A., Pereira, F., Costa, M. P., Barcelos, P., \& Carvalho, M. R. (2014). Geological Mapping of the Central Area of Terceira Island (Azores, Portugal): Associated Volcanostratigraphy, Ages and Genetic Implications on the Malha-Balcões-Chamusca Lava Caves System. Comunicações Geológicas, 101, 283-288.

Pereira, P. (2017). Author of the Aerial Photo of the Passage of the Beasts. Angra do Heroísmo: Média Nove.

Pimenta, F., Ribeiro, N., Joaquinito, A., Rodrigues, F., Costa, A., \& Silva, F. (2013). Land, Sea and Skyscape: Two Case Studies of Man-Made Structures in the Azores Islands. Culture and Cosmos, 17, 107-132.

Poehler, E. (2008). Conversation: Rush Hour in Pompeii. Archaeology, 61. http://archive.archaeology.org/0811/etc/conversation.html

Quartau, R., Hipólito, A., Romagnoli, C., Casalbore, D., Madeira, J., Tempera, F., Roque, C., \& Chiocci, F. L. (2014). The Morphology of Insular Shelves as a Key for Understanding the Geological Evolution of Volcanic Islands: Insights from Terceira Island (Azores). Geochemistry Geophysics Geosystems, 15, 1801-1826. https://doi.org/10.1002/2014GC005248

Reimer, P., Bard, E., Bayliss, A., Beck, J., Blackwell, P., Ramsey, C., Buck, C., Cheng, H., Lawrence Edwards, R., Friedrich, M., Grootes, P., Guilderson, T., Haflidason, H., Hajdas, I., Hatté, C., Heaton, J., Hoffmann, D., Hogg, A., Hughen, K., Kaiser, K., Kromer, B., Manning, S., Niu, M., Reimer, R., Richards, D., Scott, E., Southon, J., Staff, R., Turney, C., \& van der Plicht, J. (2013). IntCal13 and Marine13 Radiocarbon Age Calibration Curves 0 - 50,000 Years cal BP. Radiocarbon, 55, 1869-1887.

https://doi.org/10.2458/azu_js_rc.55.16947

Ramalho, R. S., Quartau, R., Trenhaile, A. S., Mitchell, N. C., Woodroffe, C. D., \& Avila, S. P. (2013). Coastal Evolution on Volcanic Oceanic Islands: A Complex Interplay between Volcanism, Erosion, Sedimentation, Sea-Level Change and Biogenic Production. Earth Science Review, 127, 140-170. https://doi.org/10.1016/j.earscirev.2013.10.007

Rando, J. C., Pieper, H., \& Alcover, J. A. (2014). Radiocarbon Evidence for the Presence of Mice on Madeira Island (North Atlantic) One Millennium Ago. Proceedings of the Royal Society B: Biological Sciences, 281, Article ID: 20133126. https://doi.org/10.1098/rspb.2013.3126

Resendes, T., \& Moniz, J. (2015). Sobre as Relheiras da Ilha Terceira. Pingo de Lava, 39, 42-55.

Ribeiro, N., Joaquinito, A., Rodrigues, A., \& Azevêdo, M. T. (2017). Arqueologia e Arte Rupestre na Macronésia, novos contributos. Techne, 3, 113-124.

Rodrigues, F. (2013). Megalithic Discoveries in the Azores. In Proceedings of the 16th 
Annual Mediterranean Studies Association International Congress. Angra do Heroísmo: Mediterranean Studies Association.

Rodrigues, F. (2015). Megalithic Constructions Discovered in the Azores, Portugal. Archaeological Discovery, 3, 51-61. https://doi.org/10.4236/ad.2015.32006

Rodrigues, F., Martins, N. O., Ribeiro, N., \& Joaquinito, A. (2015). Early Atlantic Navigation: Pre-Portuguese Presence in the Azores Islands. Archaeological Discovery, 3, 104-113. https://doi.org/10.4236/ad.2015.33010

Rodrigues, M., Bos, A. R., Schembri, P. J., Lima, R. F., Lymberakis, P., Parpal, L., Cento, M., Ruette, S., Ozkurt, S. O., Santos-Reis, M., Merila, J., \& Fernandes, C. (2017). Origin and Introduction History of the Least Weasel (Mustela nivalis) on Mediterranean and Atlantic Islands Inferred from Genetic Data. Biological Invasions, 19, 399-421.

https://doi.org/10.1007/s10530-016-1287-y

Rull, V., Arantza, L., Rubio-Inglés, M. J., Giralt, S., Gonçalves, V., Raposeiro, P., Hernández, A., Sánchez-López, G., Vázquez-Loureiro, D., Bao, R., Masqué, P., \& Sáez, A. (2017). Vegetation and Landscape Dynamics under Natural and Anthropogenic Forcing on the Azores Islands: A 700-Year Pollen Record from the São Miguel Island. Quaternary Science Reviews, 159, 155-168. https://doi.org/10.1016/j.quascirev.2017.01.021

Sagona, C. (2015). The Archaeology of Malta: From the Neolithic through the Roman Period. New York: Cambridge University Press. https://doi.org/10.1017/CBO9781139030465

Schneider, G. (2001). Investigating Historical Traffic Routes and Cart-Ruts in Switzerland, Elsass (France) and Aosta Valley (Italy). The Oracle, 2, 12-22.

Self, S. (1976). The Recent Volcanology of Terceira, Azores. Journal of the Geological Society, London, 132, 645-666. https://doi.org/10.1144/gsjgs.132.6.0645

Self, S., \& Gunn, B. (1976). Petrology, Volume and Age Relations of Alkaline and Satured Peralkaline Volcanics from Terceira, Azores. Contributions to Mineralogy and Petrology, 54, 293-313. https://doi.org/10.1007/BF00389409

Self, S., Gertisser, R., Kelley, S., Gaspar, J., Pacheco, J., Queiroz, G., \& Pimentel, A. (2005). The Style and Tempo of Ignimbrite Volcanism on Terceira, Azores, and Related Hazards. In Volcanic and Magmatic Study Group Annual Meeting. Milton Keynes, UK: Earth Sciences \& Geography Keele University.

USDA (United States Department of Agriculture) (1999). Soil Taxonomy: A Basic System of Soil Classification for Making and Interpreting Soil Surveys (2nd ed.). Washington DC: U.S. Government Printing Office. 